\title{
Internal locus of control, social support and academic procrastination among students in completing the thesis
}

\author{
Winda Liftiana Sari ${ }^{1}$, Fuadah Fakhruddiana ${ }^{2}$ \\ ${ }^{1}$ PT ARA, Indonesia \\ ${ }^{2}$ Faculty of Psychology, Universitas Ahmad Dahlan, Indonesia
}

\begin{tabular}{l} 
Article Info \\
\hline Article history: \\
Received Dec 23, 2018 \\
Revised Mar 10, 2019 \\
Accepted May 11, 2019 \\
\hline
\end{tabular}

Keywords:

Academic procrastination Internal locus of control

Social support

Student

\begin{abstract}
The basis of this study was to determine the relationship between internal locus of control and social support with students' academic procrastination in completing their thesis. This study is using correlational sampling technique and the research samples taken from quota sampling technique are 80 college students who are in the process of completing the thesis. The measuring instrument is the Academic Procrastination Scale in completing the thesis, Internal Locus of Control Scale and Social Support Scale. The regression analysis result that there is a very significant correlation between internal locus of control and social support with academic procrastination of the students in completing the thesis. Further analysis showed that there is a very significant negative correlation between internal locus of control with academic procrastination. This means that the lower level of internal locus of control, the higher level of academic procrastination in completing a thesis, and vice versa. Likewise, there is a very significant negative correlation between social support and academic procrastination in completing a thesis. This result means that the lower level of social support, the higher level of academic procrastination in completing a thesis, and vice versa.
\end{abstract}

Copyright (C) 2019 Institute of Advanced Engineering and Science. All rights reserved.

\section{Corresponding Author:}

Fuadah Fakhruddiana, Department of Psychology, Faculty of Psychology, Universitas Ahmad Dahlan, Kapas street 9, Semaki, Umbulharjo, Yogyakarta 55166, Indonesia Email: fuadah.fakhruddiana@psy.uad.ac.id

\section{INTRODUCTION}

The tendency to delay the completion of tasks or work generally used the term 'procrastination' [1]. The word procrastinate originates from the Latin word procrastinare and means to put off, delay, prolong, defer, stall, or postpone completing a task. Procrastination is a frequent behavior in contemporary societies [2-4]. Many people postpone work without realizing the cause. Paying bills, paying taxes, or undergoing medical examinations, is the reason for almost $20 \%$ of adults delaying their routine activities [5, 4]. Delaying activities do not only occur in the context of 'work' but also occurs in a school or academic activities. In academic activities at universities, delays in the execution of 'assignments' also often occur; also found students who often postpone assignments until the last minute [6]. Another study reported that approximately $95 \%$ of college students procrastinate [7]. Solomon and Rothblum reported that $46 \%$ of their participants always or almost always procrastinated completing term papers [8]. Procrastination that is related to academic tasks is included in academic procrastination. The procrastination behavior in completing the thesis is called academic procrastination. The truth is that procrastination occurs in all kinds of daily [4, 9], academic procrastination is very common in students and marked as detrimental to academic progress and success justify thus its study. It is estimated that academic procrastination in tasks related to academic life is a common phenomenon for about $70 \%$ of university students [4]. 
Based on the results of interviews with five college students from a university on 08 November 2016, the researcher obtained information that they procrastinated in completing their thesis. The reason students delaying their 'assignments' is because of difficulties in facing obstacles in completing their theses, such as difficulties in meeting with supervisors, difficulties in finding research subjects, and also obstacles that come from themselves such as anxiety, pessimism, and laziness. In addition, procrastination has been associated with a variety of difficulties, including test anxiety [10], missed deadlines for assignments [2], poor semester grades [11], depressed affect [12], low-esteem [8], and social anxiety [13]. Some common reasons found to be associated with procrastination are: fear of failure, feeling overwhelmed, difficulty choosing topics to learn, waiting for more information to be given in class, waiting for classmates to start so you can ask them questions, not have enough energy, other tasks require student attention, and love challenges and excitement waiting until the last minute [6]. These constraints cause the students to do the procrastination. Thus the thesis is not completed on time. This will make things worse. Anxiety and stress can arise later. Anxiety and stress experienced can increase the length of time delay due to transfer to other activities. The obstacles experienced by students of the university made him feel depressed and eventually delayed by doing more enjoyable activities, such as looking for entertainment or traveling, working in a welding workshop and leaving all activities about lectures. This student also stated that he would only work on the thesis revision if it were nearing the deadline. College students who are in the process of completing their thesis are expected to have a low level of procrastination because if they continue to procrastinate, it will make them take longer time in completing their thesis, waste time and do not maximally complete the tasks. There are still lots of college students who procrastinate which cause them unable to complete their thesis on time.

The college student also stated that he had not been doing the thesis for a week; he was eating, sleeping and playing together with his friend even though he knew that he must immediately complete his thesis. Also, other students said that he would only revise the thesis if it has been closed to the time limit. Basically, in various contexts such as work and academic activities, effective use of time has been emphasized [14, 15]. A recent meta-analysis study provides convincing evidence that there is a positive relationship between student time management and grade point average (GPA) and semester grades [15].

Although delaying behavior occurs in all types of daily tasks [13], academic procrastination occurs very commonly among students and considered detrimental to academic progress and the success of study [4]. Academic procrastination might give negative consequences because by doing procrastination, students will waste time, abandon tasks, and do not maximally complete the tasks [2]. Procrastination might relieve stress in the short term, but some researches found that procrastination itself could cause stress, even causes feeling anxious and guilty [2]. Delaying behavior can also cause delays in studying/learning [16, 17], in compiling work or reports, losing deadlines for submitting a paper, and delaying administrative tasks related to academic activities, such as returning library books, registering for examinations, etc. [18, 16, 4]. Academic procrastination also causes class skipping behavior or delaying handing over work [19], and can lead to conflicts with parents or friends [4].

Academic procrastination is a dilatory behavior which is shown in individual indicators that can be measured and observed based on its characteristics. There are four characteristics: delaying to start and complete tasks, being late in doing tasks, the time gap between plan and actual work, and doing more enjoyable activities [20].

Several factors are affecting academic procrastination in completing a thesis, both from internal and external factors. Factors that can increase academic procrastination, in general, can be classified into two categories, including internal (from the individual itself) or external (from individual perceptions to other people's attributes to them). The internal factors i.e. self-regulation learning [21], motivation [21], personality variables [4], and achievement goal orientation [22]. Some studies [23-26] associated procrastination with personality variables, such as low self-esteem, low self-confidence, high perfectionism, competitive immobilism, impulsive dysfunction, depression, and anxiety [4]. Other internal factors, such as personality traits have also been found to be related to procrastination behavior [6].

Furthermore, the locus of control allegedly also has a role in generating academic procrastination behavior. The dimensions of locus of control (internal vs. external) with other important aspects in the daily lives of students and students, such as academic achievement, self-esteem, academic procrastination, selfefficacy, optimism, self-concept, sense of mastery, etc. [13, 27-33]. In addition, as reported in [13] and [30], students with internal locus of control are less likely to conduct academic procrastination than students who have external locus of control: it means that students with internal locus of control are able to start work with the aim of completing their tasks than doing other things better than students who have external locus of control [33].

Internal locus of control is the individual's beliefs in everything that happens to them [34]. The factors within themselves, ability, interest, and effort will affect their success. Individuals who tend an

Int. J. Eval. \& Res. Educ. Vol. 8, No. 2, June 2019: 363 - 368 
internal locus of control believe that the events they experienced are the result of their behaviors and actions [35]. Internal locus of control is "the tendency of individuals to see the events they experience, whether they are good or bad, that affect themselves, are the result of their own abilities, features, and behavior, rather than the results of external forces such as luck, fate, and others" [36]. Students who tend internal locus of control understand that their academic success depends on themselves and will pay more attention to information or knowledge to achieve their targets $[36,37]$. Students who have a high level of internal locus of control will see the 'world' as something that can be controlled, so they have a decisive role in it. Students who have a high level of internal locus of control have characteristics: hardworking, have initiative, always try to solve problems encountered, always try to think as effectively as possible, and have the perception that efforts must be made if they want to be successful [38]. Thus, students who have this character will be better off using or utilizing time and showing more constructive behavior in anticipating obstacles [36]. Students who have a high level of internal locus of control will as soon as possible complete their thesis optimally and can minimize their procrastination behavior.

External factors include a negative evaluation from others [39], and peer influence [40]. Although these factors are considered external, individuals need to see them in a certain way before developing procrastination behavior [41]. Social support is verbal or non-verbal information or advice, real assistance, and actions given by social intimacy or acquired due to the presence of others, and has an emotional and behavioral benefit to the recipient [42]. Social support is a healthy relationship when the individual is experiencing problems or difficulties, either in the form of information or real help, so that individual will feel cared, appreciated, and loved. Social support can come from families, friends, and lecturers.

Social support can be divided into four dimensions: emotional support, appraisal support, instrumental support, and informative support [43]. Social support is needed by the individual, especially college students in completing their thesis. Social support can help them solve their problems, and make them feel aided and eager to finish their thesis, so the level of academic procrastination will decrease. However, the tendency of procrastination is significantly related to individual satisfaction with social and emotional support from friends rather than from family members [2].

In this context, this study aims to investigate the relationship between internal locus of control and social support with academic procrastination of the students in completing the thesis. This study is to see how the role of internal locus of control and social support in generating academic procrastination behavior.

\section{RESEARCH METHOD}

The population of this study was 324 students in a faculty at particular universities in Yogyakarta, Indonesia, who are in the process of completing their thesis. The sample of this research was 80 students selected through a quota sampling technique.

The data was obtained using a scale of academic procrastination, the scale of internal locus of control, and scale of social support. Determination of the number of scale items is calculated using the Brown-Spearman scale formula based on reliability and the expected average correlation scale item. The scale compiled by the researcher is a Likert model scale. The Likert Scale is a bipolar scale method that measures both positive and negative responses to a statement. The scale used in this study is the scale prepared by the researcher. The Scale of Academic Procrastination compiled based on specific characteristics according to Schouwenberg [5] consisting of delay to start and complete tasks, delay in doing tasks, time gaps between plans and actual performance, and doing other pleasant activities. The scale consists of 31 items and Cronbach's alpha coefficient of scale is 0.13 .

The scale of internal locus of control compiled based on characteristics of Internal Locus of Control according to Crider [1] i.e. like working hard, having high initiative, always try to find problem-solving, always try to think effectively as possible, and always have a perception that effort must be made to gain success. This scale has 42 items and Cronbach's alpha coefficient is 0.938. The scale of Social Support compiled based on the dimensions of social support according to the House i.e. emotional support, award support, instrumental support and informative support [43]. The scale of Social Support had 36 items and Cronbach's alpha coefficient of scale is 0.955 .

The validity used in this study is content validity, which is validity that is estimated by testing the content of the test through rational by professional judgment. The data analysis method used in this study is regression analysis as this research test the relationship between internal locus of control and social support variables and academic procrastination variable. Before data analysis, the assumption test was performed. The data in this study were analyzed using a statistical computation method with SPSS 16.0 for Windows. 


\section{RESULTS AND DISCUSSION}

Based on the results of data analysis, the regression coefficient between internal locus of control and social support with academic procrastination in completing a thesis is $\mathrm{R}=0.782$ with $\mathrm{p}=0.000$. From this statistical data, there is a very significant connection between internal locus of control and social support with academic procrastination in completing a thesis.

Based on the results of partial correlation analysis between internal locus of control and academic procrastination, the coefficient correlation between internal locus of control and academic procrastination in completing a thesis is Zero-order $=-0.704$ with $p=0.000$. The result of this computation showed that there is a very significant negative correlation between internal locus of control and academic procrastination in completing a thesis. This result means that the lower level of internal locus of control, the higher level of academic procrastination, and vice versa.

College students with a high level of internal locus of control will be more actively seeking information and use it to solve their problem, have a high sense of responsibility, always try to and complete their thesis immediately. While students with a low level of internal locus of control will be less actively seeking information to solve their problem, and do not like trying to complete their tasks because they are not sure about their ability, so they tend to procrastination.

As reported in previous research $[13,30]$ as mentioned earlier, students with internal locus of control tend to do academic procrastination less regularly than those with external locus of control: this means that students with internal locus of control are able to start work with the aim of completing their tasks better than those students with external locus of control [33]. Students with high internal control for academic results need less time to complete and restore academic assignments than students with high external controls [13]. Low level of internal locus of control might cause procrastination behavior because students might feel unsure about their own ability to complete their thesis and then prefer to do more enjoyable activities, though, in the end, they blame the objects outside themselves.

Based on the results of partial correlation analysis between social support and academic procrastination, it is recognized that Zero-order $=-0.618$ with $p=0.021$. This result shows that there is a significant negative correlation between social support and academic procrastination. The negative correlation means that the lower level of social support, the higher level of academic procrastination in completing a thesis, and vice versa.

The social support that the college students get will affect how they solve their problem. A high level of social support will help them to motivate themselves to complete their thesis so that procrastination behavior can be diminished. Without social support, students will feel stressed; and from the information, the researcher got from several students, that they feel incapable of finishing their thesis without the support from friends and families. One study has shown a negative relationship between social support and procrastination in students [2]; however, the results found a correlation between social support and procrastination. This shows that social support contributes to the emergence of procrastination behavior.

In this research, the result of academic procrastination categorization in completing thesis from the research subjects showed that $82.5 \%$ are in the medium category, $17.5 \%$ are in a low category, and $5 \%$ are in the high category. The result of this computation concluded that the majority of research subjects (college students) quite often do the procrastination both in starting or completing the thesis.

The results of data analysis revealed that the magnitude of the correlation coefficient between the internal locus of control variables and academic procrastination in completing the thesis obtained a Zeroorder score $=-0.704$ with a value of $p=0.000$. This calculation showed that there is a very significant negative relationship between internal locus of control and academic procrastination in completing the thesis, while the magnitude of the correlation coefficient between the variables of social support and academic procrastination in completing the thesis is obtained Zero-order score $=-0.618$ with $p=0.021$. Of the two variables, which play a greater role in determining academic procrastination is the internal locus the of the control variable. The belief that what determines one's success is everything that happens to him, because of factors from within himself, the ability, interest, and effort in him self; will contribute more in reducing the emergence of academic procrastination behavior. Someone will try to complete his tasks because he believes that the success of his studies is more determined by his own efforts. Social support also provides a role in reducing the emergence of academic procrastination behavior. Someone who gets support from other people, it will be more motivated to complete their tasks.

Based on the calculation of the coefficient of determination, it is known that $\mathrm{R} 2=0.530$. This means that internal locus of control and social support give an effective contribution as much as $53 \%$ (R squared $0.530 \times 100 \%$ ) to academic procrastination. This also can be assumed that academic procrastination can be affected by other factors besides internal locus of control and social support by $47 \%(100 \%-53 \%)$. Both variables play a role in determining the emergence of academic procrastination behavior. A strong belief that success is more determined by him and that there is strong support from outside parties will reduce the

Int. J. Eval. \& Res. Educ. Vol. 8, No. 2, June 2019: 363 - 368 
emergence of academic procrastination behavior. Therefore synergy between the two variables is needed in encouraging individuals to complete their study assignments.

\section{CONCLUSION}

It is inferred that there is a very significant correlation between internal locus of control and social support with academic procrastination in completing a thesis. Moreover, based on further analysis, there is a very significant negative correlation between internal locus of control and academic procrastination in completing a thesis. This finding means that the lower level of internal locus of control, the higher level of academic procrastination in completing a thesis, and vice versa. Likewise, there is a significant negative correlation between social support and academic procrastination in completing a thesis. This result means that the lower level of social support, the higher level of academic procrastination in completing a thesis, and vice versa. The analysis showed that the internal locus of control and social support variables makes an effective contribution of 53\% to academic procrastination in completing the thesis, so it can be assumed that there are still $47 \%$ of other factors that affect academic procrastination in completing the thesis.

The results of this study have been supported by the results of previous research so that it can be more convincing. Combination of internal locus of control and social support is great in determining someone to complete their tasks. Students or someone who has a high internal locus of control will see the world as something that can be controlled so that his behavior plays a role in it, so this belief will encourage him to complete his thesis/tasks. Also supported by the existence of outsiders who provide facilities, easiness, material and non-material support, it will further encourage someone or students to complete their tasks or thesis.

It can be recommended for universities, that it is necessary to provide psychoeducation for their students so that they have confidence that what determines success is more than themselves. Outsiders actually also contribute, but more are things that are in themselves. Cooperation is needed from students, universities, and parents to encourage the success of these students. Parents also need to care more about their children to have a strong belief that what determine success are themselves. With the internal locus of control that is owned, someone will be more able to control themselves and try to complete the task according to the time given.

\section{REFERENCES}

[1] J. Burka and L. Yuen, "Procrastination: Why You Do It. What To Do About It," New York: Perseus Books, 1983.

[2] J. Ferrari, J. Jhonson and W. McCown, "Procrastination and Task Avoidance: Theory, Research, and Treatment," New York: Plenum Press, 1995.

[3] J.R. Ferrari, J. O'Callaghan, dan I. Newbegin, "Prevalence of Procrastination in the United States, United Kingdom, and Australia: Arousal and Avoidance Delays among Adults," North American Journal of Psychology, vol. 7, pp. $1-6,2005$.

[4] P. Rosário, M. Costa, J.C Núñez, J. González-Pienda, P. Solano, and A. Valle, "Academic Procrastination: Associations with Personal, School, and Family," The Spanish Journal of Psychology, vol. 12, no. 1, pp. $118-127,2009$.

[5] H.C. Schouwenburg, "Trait Procrastination in Academic Settings: An Overview of Students who Engage in Task Delays," In H.C. Schouwenburg, C. Lay, T. Pylchyl, \& J. Ferrari, (Eds.), Counselling The Procrastinator in Academic Settings, pp. 3-18, Washington: American Psychological Association, 2004.

[6] M. Philips, "Does Locus of Control Task Interest Have an Effect on Procrastination?," The Huron University College Journal of Learning and Motivation, vol. 50, issue 1, article 8, 2012.

[7] A. Ellis and W.J. Knaus, "Overcoming Procrastination," New York: Institude for Rational Living, 1977.

[8] L.J. Solomon and E.D. Rothblum, "Academic Procrastination: Frequency and Cognitive Behavioral Correlates," Journal of Counseling Psychology, vol. 31, pp. 503-509, 1984.

[9] E.S., Alexander and A.J Onwuegbuzie, "Academic Procrastination and The Role of Hope as a Copyng Strategy," Personality and Individual Differences, vol. 38, pp. 1771-1780, 2007.

[10] G. Beswick, E.D. Rothblum, and L. Mann, "Psychological Antecedents to Student Procrastination," Australia Psychologist, vol. 23, pp. 207-217, 1988.

[11] C.H. Lay, "A more profile Analysis of procrastination: A search for types," Personality and Individual Differences, vol. 8, pp. 705-714, 1987.

[12] C.H. Lay, "At Last, My Research on Procrastination," Journal of Research in Personality, vol. 20, pp. 474-495, 1986.

[13] T. Janssen, and J.S. Carton, "The Effects of Locus of Control and Task Difficulty On Procrastination," The Journal of Genetic Psychology, vol. 160, no. 4, pp. 436-442, 1999.

[14] B.J.C. Claessens, W. van Gerde, C.G. Rutte, and R.A. Roe, "A Review of the Time Management Literature," Personal Review, vol. 36, pp. 255-276, 2007.

[15] S. Won and S.L. Yu, "Relations of Perceived Parental Autonomy Support and Control with Adolescents' Academic Time Management And Procrastination," Learning and Individual Differences, vol. 61, pp. 205 - 2015, 2017. 
[16] E. Rothblum, L. Solomon, and J. Murakami, "Affective, Cognitive, and Behavioural Differences Between High and Low Procrastinators," Journal of Counselling Psychology, vol. 33, pp. 387- 394, 1986.

[17] D. Tice and R. Baumeister, "Longitudinal Study of Procrastination, Performance, Stress, and Health: The Costs and Benefits of Dawdling," Psychological Science, vol. 8, pp. 454-458, 1997.

[18] S. Scher and J. Ferrari, "The Recall of Completed and Noncompleted Tasks through Daily Logs to Measure Procrastination," Journal of Social Behaviour and Personality, vol. 15, pp. 255-265, 2000.

[19] S. Scher, and Osterman, N., "Procrastination, Conscientiousness, Anxiety, and Goals: Exploring the Measurement and Correlates of Procrastination among School-Aged Children," Psychology in the Schools, vol. 39, pp. 385-398, 2002.

[20] H.C. Schouwenburg, "Procrastinator and Fear of Failure: An Exploration of Reason for Procrastination," Europen Journal of Personality, vol. 6, no. 3, pp. 225-236, 1992.

[21] C. S. R. Koestiner and R. J. Vallerand, "Self-Regulation and Academic Procrastination," The Journal of Social Psychology, vol. 135, no. 5, pp. 607-619, 1995.

[22] A. J. Howel and D. C. Watson, "Procastination: Associations with Achievement Goal Orientation and Learning Strategies," Personal and Individual Differences, vol. 43, pp. 167-178, 2007.

[23] J.R. Ferrari \& J.F. Díaz-Morales, "Perceptions of Self-Concept and Self-Presentation by Procrastinators: Further Evidence," The Spanish Journal of Psychology, vol. 10, no. 1, pp. 91-96, 2007.

[24] J.R. Ferrari dan R. Emmons, "Methods of Procrastination and Their Relation to Self Control and SelfReinforcement," Journal of Social Behaviour and Personality, vol. 10, pp. 135-142, 1995.

[25] G. Flett, P. Hewitt, dan T. Martin, "Dimensions of Perfectionism and Procrastination," In J. R. Ferrari, J. Johnson, \& W. McCown, (Eds.), Procrastination and Task Avoidance: Theory, Research and Practice, pp. 113-136, New York: Plenum Press, 1995.

[26] W. van Eerde, "A Meta-Analytically Derived Nomological Network of Procrastination," Personality and Individual Differences, vol. 35, pp. 1401-1418, 2003.

[27] S. Findley and V. Cooper, "Academic Locus of Control: A Relevant Variable at Tertiary Level," Higher Education Journal, vol. 5, pp. 251-257, 1983.

[28] R. Abouserie, "Sources and Levels of Stress in Relation to Locus of Control and Self-Esteem in University Students," Educational Psychology: An International Journal of Experimental Educational Psychology, vol. 14, pp. 323-330, 1994

[29] Y.S. Park and U. Kim, "Locus of Control, Attributional Style, and Academic Achievement: Comparative Analysis of Korean-Chinese, and Chinese students," Asian Journal of Social Psychology, vol. 1, pp. 191-208, 1998.

[30] B.L. Beck, S.R. Koons, and D.L. Milgrim, "Correlates and Consequences of Behavioral Procrastination: The Effects of Academic Procrastination, Self-Consciousness, Self-Esteem and Self-Handicapping," Journal of Social Behavior \& Personality, vol. 15, pp. 3-13, 2000.

[31] T. Jackson, K.E. Weiss, and J.J. Lundquist, "Does procrastination mediate the relationship between optimism and subsequent stress?," Journal of Social Behavior and Personality, vol. 15 , pp. 203-212, 2000.

[32] M.K. Nilson-Whitten, B. Morder, and G.M. Kapakla, "Relationship between locus of control, optimism and academic performance," Proceedings of the Annual Conference of the New Jersey Counseling Association Eatontown, New Jersey, 2007.

[33] E. Sagone, and M.E. De Caroli, "Locus of Control and Academic Self-efficacy in University Students: The Effect of Self-concepts," Procedia-social and behavioral sciences, vol. 114, pp. 222-228, 2013.

[34] E. Phares, Locus of Control in Personality, Morristown, N.J.: General Learning Press, 1976.

[35] J. Rotter, "Generalized Expectancies for Internal versus External Control of Reinforcement," Psychological Monographs: General and Applied, vol. 80(1), 1-28, 1966.

[36] M. Deniz, Z. Tras and D. Aydoğan, "An Investigation of Academic Procrastination, Locus of Control, and Emotional Intelligence," National Congress of Psychological Counseling and Guidance, pp. 623-632, 2009.

[37] M.J. Burger, "Kişilik" (çev. İ. D. Erguvan Sarığlu), İstanbul: Kaknüs Yayın- ları, 2006.

[38] A. Crider, "Psychology," Scott: Foresman \& Company, 1983.

[39] C.D. Saddler and J. Buley, "Predictors of Academic Procrastination in College,".

[40] X. Shi, S. Wang, S. Liu, T. Zhang, S. Chen and Y. Cai, "Are Procrastinators Psychologically Healthy? Association between Psychosocial Problems and Procrastination among College Students in Shanghai, China: A Syndemic Approach," Psychology, Health, \& Medicine, Retrieved from http://www.tandfonline.com/loi/cphm20, pp. 1-8, 2018.

[41] K. Prihadi, C.Y.H. Tan, R.T.S. Tan, P.L. Yong, J.H.E. Yong, S. Tinagran, C.L. Goh, Y.J. Tee, "Motivation Role of Locus of Control on Relationship of Learned-Helplessness and Academic Procrastination," International Journal of Evaluation and Research in Education (IJERE), vol. 7(2), pp. 87-93, 2018.

[42] B. Gottlieb, "Social Support Strategies," Beverly Hills CA: Sage Publication, Inc., 1983.

[43] B. Smet, "Health psychology," Jakarta: PT. Grasin, 1994.

[44] S. Azwar, "Reliability and Validity," Yogyakarta: Pustaka Pelajar, 2013.

[45] S. Azwar, "Research Method," Yogyakarta: Pustaka Pelajar, 2014.

Int. J. Eval. \& Res. Educ. Vol. 8, No. 2, June 2019: 363 - 368 